\title{
Kırmızı Pazartesi ve Kuyucaklı Yusuf Romanlarının Toplumcu Gerçekçi Ve Sosyolojik Eleştiri Bağlamında Karşılaştırmalı Analizi
}

A Comparative Study of Kırmızı Pazartesi and Kuyucaklı Yusuf in the Context of Socialist Realism and Social Criticism

\section{Ferhan Öztürk*}

Öz

Edebiyat her kültür içerisinde şekillenmiş toplumsal yapı ve değerleri doğal olarak yansıtan bir estetik araçtır. Yazarlar kendi toplumlarının içinden çıkan birer fert olarak bu estetik aracı çeşitli nedenlerle kullanarak farklı türlerde eserler verirler. Bu bağlamda bilinçli ya da bilinç dışı süreçler sonucunda yazınsal eserlerin metninde o topluma ait kültürel ipuçlarına rastlanır. Bu anlayışla bu makale üzerinden toplumsal değerlerden namus algısı bağlamındaki kadın ve erkek rolleri, din olgusu, sosyal statü ve imtiyaz ile suç kavramı üzerinden karşılaştırmalı bir okuma yapılmıştır. Karşılaştırılan eserler Latin Amerika kültürünün önemli yazarlarından Gabriel García Marquez'in Kırmızı Pazartesi adlı kısa romanı ile Türkçe edebiyatın büyük ustalarından Sabahattin Ali'nin Kuyucaklı Yusuf adlı romanıdır. Makalenin teorik alt yapısı Berna Moran'ın Edebiyat Kuramları ve Eleştiri kitabında yer verdiği Toplumcu Gerçekçi ve Sosyolojik Eleştiri yaklaşımları ekseninde şekillenmiştir. Bu iki yaklaşıma göre sanat hayatı doğrudan yansıtan bir araç işlevindedir ve toplumsal dinamikler sosyal, ekonomik ve politik unsurların şekillendirmesiyle oluşur. Her iki romanın kurgusunda işlenmiş toplumsal değerler kitaptan örneklerle karşılaştırmalı olarak ele alınmıştır. Bu çalışma sonucunda her iki toplum modelinde toplumsal değerler bakımından benzerlikler tespit edilmiştir. Her iki toplumda namus anlayışı konusunda sürdürülen çifte standardın varlığı, dinin bireylerin gündelik yaşamı içerisindeki işlevsizliği,

Doktora Öğrencisi, İstanbul Üniversitesi, Sosyal Bilimler Enstitüsü, Karş1laştırmalı Edebiyat, ferhano@ogr.iu.edu.tr

$\mathrm{Bu}$ makale Thenticate sistemi tarafından taranmıştır.

Makale Gönderim Tarihi: 16 Ağustos 2020 
Ferhan Öztürk

zenginlik ve varlıklı olmanın toplumsal dokunulmazlık ve üstünlük sağlayan konumu ve suç kabul edilen eylemlerin yine toplumsal imtiyaz ve çifte standartlı sebepleri nedeniyle bireylerin hayatını olumsuz yönde etkilediği görülmüştür.

Anahtar Kelimeler: Toplumcu Gerçekçi, sosyolojik eleştiri, toplumsal cinsiyet, sosyal statü, din olgusu. 


\section{Abstract}

Literature is an aesthetic means reflecting the social structure and values shaped within each culture. Writers as individuals emanating from their own cultures have used this aesthetic means to produce literary works for various reasons. In this regard, having resulted from either conscious or unconscious processes, one is sure to detect cultural leads within these literary texts. Therefore, this article is a comparative study looking into gender roles in the context of honour affairs, religion as a social phenomenon, social privilege and the concept of crime as examples to social values. The selected works are the novella Chronicle of a Death Foretold by the prominent Latin American writer Gabriel García Marquez and Kuyucaklı Yusuf by the great Turkish author Sabahattin Ali. The theoretical background of the article is based on the critical approaches of socialist realism and social criticism as stated by Berna Moran in his boo Edebiyat Kuramları ve Eleştiri (Literary Theories and Criticism). According to these two approaches art is reflective of life and social dynamics are shaped due to social, cultural, economic and political elements. The social values under scrutiny are studied in a comparative and textual fashion based on excerpts taken from both works of literature. As a result, it has been identified that both novels reveal similarities in terms of the presentation of societal values. In both societies a double standard for honour affairs exists. Moreover, the presence of religious dysfunctionality, a privileged supremacist status stemming from wealth and social affairs, and crime as a result of societal double standards have a negative effect on the lives of individuals.

Keywords: Socialist Realism, social criticism, gender, social status, religion. 


\section{Giriş}

Kültürel kökenleri farklı olsa da edebiyat eserleri içinden çıktıkları topluma ve o toplumu oluşturan unsurlara ayna tutarlar. $\mathrm{Bu}$ eserlerin farklı kurgularla okuyucuya ulaştırdığı kültürel içeriğin de aslında özünde benzerlik taşıdığı ve insana dair konuları işledikleri görülür. Bu benzerlikler insanın doğasına işaret eden psikolojik ve sosyolojik gerçeklere ulaştırır okuyucuyu. Bu bağlamda seçilen ve tamamen farklı iki coğrafya ve kültüre ait iki roman üzerinden ortak bir söylem ve gerçekliğe 1şık tutulacaktır. Bu romanlardan ilki Kolombiyalı ve Nobel ödüllü yazar Gabriel Garcia Marquez'in dilimize Kırmızı Pazartesi (nam-1 diğer İşleneceğini Herkesin Bildiği bir Cinayetin Öyküsü) olarak çevrilen kısa romanı ile Türk edebiyatının tanınırlığı ve edebi etkisi gün geçtikçe artan usta kalemi Sabahattin Ali'nin Kuyucaklı Yusuf adlı eseridir. Kırmızı Pazartesi 1981 yılında yayınlanmasına rağmen 1950'li yılların Kolombiya-Latin Amerika toplumunu anlatırken, Kuyucaklı Yusuf 1937' de kaleme alınıp kendi döneminin toplumsal hayatını içerden bir gözle edebiyata kazandırılmıştır. Bu iki roman üzerinden her iki toplumun namus anlayışı, maddi güç ve sosyal statünün birey ve toplum hayatındaki belirleyiciliği, dini anlayışın etkisi ve toplumsal değer yargılarının bireylere olan baskısı Berna Moran'ın derlediği Edebiyat Kuramları ve Eleştiri kitabı başlıklarından Toplumcu Gerçekçi ve Sosyolojik Eleştiri açılarından incelenecektir.

Öncelikle her iki eleştiri türünün bazı alt açılımları bu çalışmadaki kapsamları açısından kısaca ele alınacaktır. Toplumcu Gerçekçilik 1930'lu yıllarda ortaya çıkmış metin boyutlu bir yaklaşım ve eleştiri türü olarak sanata yansitma perspektifinden bakar. Toplumun ve bireylerin mevcut hali yansıtılmaya çalışılırken aslında bir sonraki toplumsal gerçeklik de gösterilmek istenir. Çoğunlukla bu yansıtmanın içeriğinde olumsuz seyreden durumlar vardır ve edebi kurgu içerisinde bir öz halinde yer alır. Bu özü şekillendirip yansıtan tipik karakterler vardır ve kendi sosyal ve tarihi bağlamları içerisinde sunulurlar. Tipik karakterler kadar bir de olumlu kahramanlar ön plana çıkarılır. Bunlar genellikle parlak zekâlı, duyarlı ama karamsar, topluma karşı olumsuz, bir işe yaramaz 
ve eyleme geçemeyen, hep yenilgiye uğrayan kişilerdir (Moran, 1999: 53-61). Bektaş'in da vurguladığı gibi "folklor ürünlerinden ödünçleme ve yeniden konumlandırma yoluyla yaratılan bu kahramanlar, halkın mutluluğu için kendi arzularından vazgeçen fedakâr tiplerdir" (2009: 47). Bu çalışmada seçilen bütüncelerin hangi oranda topluma ayna tuttukları ve bünyelerinde tipik veya olumlu karakterler barındırıp barındırmadıkları belirlenmeye çalışılacaktır. Öte taraftan sosyolojik eleştiride, yazar, eser ve okurun sosyal koşullar tarafından belirlendiğine hükmedilir ve eserlerin içinden çıtıkları toplumun iklimsel, fiziksel, politik ve sosyal koşulları tarafından şekillendirildiği kabul edilir. Betimleyici bir anlatıma sahip olan sosyolojik eleştiri yine toplumsal gerçekçilikte olduğu gibi toplumu yansitırken (Moran, 1999: 83-85) aynı zamanda artalan şartlarını betimleyerek sorunları sebepleriyle hissettirmeye çalışmaktadır. Mehmet Karakaş’a göre toplumun sosyolojik düşüncenin temel odak noktası haline gelmesi sosyolojinin bir bilim olarak ilk dönem teorilerinin makro düzeyde ele alınmasından kaynaklanmış ve en önemli araştırma nesnesi olan sanayi toplumu çeşitli dinamikleriyle ortaya çıkmıştır (2002: 161). Toplumsal olanın bu denli yakından irdelendiği bir yaklaşımdan beslenen sosyolojik eleştiri de böylece edebi incelemelerin temel sacayaklarından biri haline gelmiştir.

\section{Kırmızı Pazartesi'de Namus, Sosyal Statü-Değer ve Din Olgusu}

Gelmiş geçmiş en büyük Kolombiyalı olarak tanımladığı G. G. Marquez'in kısa romanı Kırmızı Pazartesi'deki kurguyu 1951 yılında Kolombiya'da meydana gelen gerçek bir hikâyeden esinlenerek yazdığını aktarmaktadır Ed Vulliamy (2014). Hatta Marquez'in bu olayın çocuk tanıklarından biri olduğu iddia edilmektedir (Darıcı, 2017). Buna göre gerçek adı Margarita Chica Salas olan bir kadın bir başkası ile olan ilişkini itiraf ettiğinden ötürü kocası tarafından terk edilir ve akabinde kadının abileri de namuslarına sürülen lekeyi genç tıp öğrencisi delikanlıyı öldürerek temizlerler. Yaşadığı kasabadan ayrılmak zorunda kalan Salas yirmi yıl sonra eskiden evlendiği kocasına âşık olduğunu fark ederek tekrar bir araya gelmeye çalışır. Her ne kadar bu olay mutlu sonla bitmese de ortada uzun yıllara yayılan bir aşk ger- 
çeği vardır. Öte taraftan Bowdoin Üniversitesi Latin Amerika Çalışmaları bölümünde yönetici olan Prof. Dr. Nadia Celis, yazara dair yaptığı arşiv taramasından elde ettiği belgelere dayanarak G.G. Marquez' in, her ne kadar yayınlanmasa da, bu kitabına yazdığı son sözde hikâyedeki suç teması kadar aşk temasını da odak noktası olarak ele aldığını belirttiğini ifade etmektedir. Marquez'e göre bu hadise korkunç/ kötü bir aşkın gizli bir hikâyesidir. G. G. Marquez bu hikâye üzerinden Kolombiya toplumunun ataerkil yapısını ve yaygın görülen maçoluğu ele alarak bir cinayetin köylülerin de bir nevi suç ortaklığ1 yapmasıyla meydana gelişini ve mağdur gelin Angela Vicario' nun bu olaylardan nasıl etkilediğini irdelemektedir (Porter, 2018).

Marquez'in anlatısı üzerinden bakıldığında Kolombiya toplumunun açmazları ve sorunlarının eleştirel bir bakışla yansıtıldığı görülür. Anlatıdaki kurguya göre Kolombiya'nın bir kasabasında herkesin bildiği fakat sadece öldürülecek olan Santiago Nasar'ın kendisinin bilmediği bir "namus" cinayeti anlatılmaktadır. Bir başkasıyla evlenecek olan Angela Vicario'nun bekâretini bozup onurunu lekelediği iddia edilen Santiago Nasar, kızın ikiz erkek kardeşleri (Pablo- Pedro Vicario) tarafından hunharca katledilir. İşin ilginç yanı işlenecek cinayetin daha ilk satırdan okura ve kasabadaki diğer kişilere bildirildiğidir fakat kasaba halkı bunu engellemek adına hiçbir şey yapmayacaktır. Hikâyedeki toplumun sosyo-kültürel yapısını yansıtırken Marquez gazeteci olarak çalıştığı gençlik yıllarından kalma bir alışkanlıkla farklı kişilerin aynı olayla ilgili ama birbiriyle çelişen şahitliklerine kurgusunda yer vermiştir. Bu şekilde tek bir gerçeğin (!) kişilerdeki değişken ve güvenilmez algılanışını sorgulamış ve bu namus cinayetinin çelişkilerle dolu arka plan ayrıntılarını okura sunmak istemiştir. Bundan yola çıkarak da aslında toplumun gerçek diye dayattığı her şeyin adeta birey tarafından sorgulanması gerektiğini anlatmak istemektedir ki buna kanıt olarak kitapta bahsi geçen cinayetin işlendiği günün hava durumuna ait birçok farklı anının hikâye kahramanlarının zihninde yer ettiği gösterilebilir. O gün hava kimilerine göre yağmurlu, kimilerine göre ise kesinlikle kurudur. İlginçtir ki bireyler kendi aralarında kişilikçe ve olayın ayrıntıları- 
nı hatırlama ve anlamlandırmada çelişik olmalarına karşın, değer yargıları konusunda hemfikirdirler; Santiago Nasar bu suçunun cezasını ölerek çekmelidir.

Yazar Marquez bu çelişkili şahitlikler içerisinde toplumun erkek ve kadına biçtiği rolleri de irdelemiştir. Kolombiya-Latin Amerika toplumu oldukça ataerkil ve cinsiyet rolleri konusunda dayatmacıdır. Rex A. Hudson önemli çalışmasında geleneksel manada Kolombiya toplumunun aile yapısının katı bir hiyerarşiye sahip ve erkek egemen olduğunu belirtmektedir. Otoriter ve eril bir yaklaşım ile şekillenen kadın erkek ilişkileri kadınların namus ve erdemliliğinin erkekler tarafından kontrol edildiği bir toplumsal yapıdad $\imath$. Kadınların ailelerindeki erkeklerin beklenti ve rahatlarmı baz alarak ev işleri ile çocuklara dair görev ve sorumluluklarını yerine getirmeleri en belirgin faaliyetleri olarak kabul edilmektedir (2010: 104107). Bu olguyu destekler özellikte çokça örnek vardır kitapta. Örneğin Pura Vicarión nun (mağdur Angela'nın annesi) kızları;

...evlenmek üzere yetiştirilmişlerdi. Gergef işlemeyi, makineyle dikiş dikmeyi, kukalı dantel örmeyi, çamaşır yıkayıp ütü ütülemeyi, yapma çiçekler, kendi uydurdukları tatlılar yapmayı, aşk pusulaları yazmayı bilirlerdi. Ölüme saygıyla yaklaşma kültürünü bir yana bırakmış zamane kızlarından farklı olarak, onların dördü de eskiden adet olduğu gibi hastaların başında bekleme, ölüm döşeğinde olanlara güç verme, ölüleri kefenleme sanatında birer ustaydilar. (Marquez, 2014: 34)

Toplumun kadınları yetiştirme anlayışı damat adaylarını mutlu etmek üzerine kuruludur çünkü hikâye anlatıcısının annesinin de dediği gibi, "Her erkek onlarla mutlu olur, çünkü acı çekmek için yetiştirilmişler" (Marquez, 2014: 34). Diğer taraftan erkeğe biçilen role gelindiğinde de, "Oğlanlar erkek adam olacak şekilde büyütülmüşlerdi" (Marquez, 2014: 34) söylemi ile karşılaşılmaktadır. İşte böylesi bir toplumda adam öldürme için kabul edilebilir görülen sebeplerin en başında namusa sürülen leke gelmektedir. Kadınların bağımsız olarak görülmediği ataerkil toplumlarda kadınlar sadece bir erkeğin eşi ya da çocuklarının annesi konumunda bulunabilirler. Bu konumların gerektirdiği rolleri benimsemek statü kazanmak ve eril baskıdan bir nebze uzak olabilmek için 
tek çıar yol gibi görünmektedir. Hatta Deniz Kandiyoti ataerkil toplumlarda yaşayan kadınların bu itaatkâr tutumunu "ataerkil pazarlık” olarak tanımlamaktadır (Yüksel vd. , 2017: 204). Söz konusu bu pazarlıktan nasibini alan biri de romandaki Angela Vicario karakteridir. Sevmeden evlenmek zorunda olduğu kocası Bayardo San Roman tarafından daha dügün gecesi bakire olmadığı anlaşılınca gecenin bir vakti babasının evine teslim edilir. Bu utanç yüzünden annesinden fena dayak yiyen Angela namusuna leke süren kişinin kimliğine dair ailesine bir isim vermek zorundadır. Verdiği isim (Santiago Nasar) roman süresince suçlanır ama farklı tanıklıklardan iz sürerek okur Santiago'nun suçsuz olabilme ihtimaline de hükmeder. Ataerkil anlayışa sahip bir toplumun fertleri olan Pablo ve Pedro Vicario adlı ikizler kız kardeşlerinin namusunu temizlemek zorundadırlar. Her ne kadar bunu yapma konusunda ayak direseler de nihayetinde cinayeti herkesin gözü önünde işlerler. İkizler aslında isteksizdirler ve bunu cinayeti işleyeceklerini herkese anlatarak dolaylı olarak hissettirirler. Hal diliyle birileri onları durdursun isterler ama namus konusunda çifte standartları olan toplum bu konuda sessiz kalır. Tüm kasaba durumu bildiği halde sadece tek bir kişi Santiago'ya durumu haber verir; "Biri çıkıp da onu öldürmelerini engellesin diye akla gelebilecek her çareye başvurmuşlar ama bunu sağlamayı başaramamışlardı" (Marquez, 2014: 49).

Toplumun çifte standardı evlilik öncesi bekârete önem veren toplumun ayn hassasiyeti erkekten beklememesinde de gözlemlenebilmektedir. Kasabadaki erkeklerin dügüun gecesi eğlencesinde civardaki genelevde vakit geçirmeleri hoş ve normal karşılanmaktadır. Hatta bu evin en sevilen kadını olan Maria tüm kasabanın yakinen tanıdığı biridir; “...kapıları herkese açık bir evde, burada yaşıyordu. Benim kuşağımın bekâretini silip süpüren de o olmuştu. Öğrenmemiz gerekenden çok daha fazlasın öğretmişti bizlere, ama her şeyin üstünde de hayatta hiçbir yerin boş bir yatak kadar hüzünlï olamayacă̆ını öğretmişti" (Marquez, 2014: 61). Başka bir kad1nın kadınlığından faydalanırken bir başkasının kendi gözetimi altında gördüğü bir kadından faydalanmasından rahatsızlık duyulmasındaki mantıksal çelişki toplumda yanlış şekillenmiş örf 
ve adetlerin süregelmesinde aranmalıdır belki de. Belirleyiciliği küçük gruplarda şekillenmiş yüz yüze, gündelik samimi ve duygusal davranış örüntülerine dayanan birincil ilişkilerdeki çift değerli davranış motifleri bireyleri kimi zaman toplumsal anlamda korurken kimi zaman da belli suçların işlenmesine itebilmektedir (Yildırım, 2014: 4).

Romanların karşılaştırılmasındaki bir başka izlek de din olgusudur. Kolombiya toplumundaki dini anlayışı çalışmasında irdeleyen Rex A. Hudson, Latin Amerika coğrafyasındaki ortalamaya göre Kolombiyalı din otoritelerini oldukça tutucu olarak tanımlamaktadır (2010: 50). Her ne kadar yıllar içerisinde kilisenin gücü azalmaya yüz tutmuş olsa da yine de toplumsal hayat içerisinde önemli bir işlevi var olmaya devam etmektedir (2010: 119). Bu bağlamda Héctor Hoyos da G.G. Marquez' in romanlarında Katolik inancının ikircikli yapısına vurgu yaptığını iddia etmektedir. Buna göre Marquez'in yazınında Katolik inancı ne önemsizdir ne de görmezden gelinecek bir konumdadır (2006: 19). Bu kararsız ara konum romandaki kasaba halkının namus konusundaki yanlı tutumunun din söz konusu olunca da benzer bir eğilim göstermesi ile örneklendirilebilir. Romanda din teması Peder Carmen Amador ve Piskopos karakteri üzerinden okura sunulmaktadır. Peder, Santiago'nun öldürüleceğini bilse de "ne yapacağı(n)1 bilememişti"r ve kendince çözümü "sivil yetkililere" havale etmiştir (Marquez, 2014: 65). Cinayetin işleneceği gün tüm kasaba halkı kasabayı ziyarete gelecek olan piskoposu büyük bir heyecanla beklemektedir. Peder de piskoposun horozibiği çorbası merakı için "...en iştah açıcı ibiklere sahip horozları kendi elleriyle seçmişti" (Marquez, 2014: 23) yorumunu yapmaktadır. Bu durumun alaycı bir şekilde eleştirilişi karakterlerden birinin; “Doğrusunu istersen... Çorba yapmak için yalnızca ibiklerini kesip horozlarm geri kalanın çöpe adan bir adam tarafindan kutsanmak istemiyordum ben" (Marquez, 2014: 23) demesinde hissedilebilmekte ve dinin şekilciliğine, kavramın içinin boşaltılmışlığına ve din adamlarının niteliklerinin bozulmuş olmasına dair ciddi bir eleştirinin yapıldığı anlaşılabilmektedir (Tepeler, 2013). Yazar tarafından eleştirilen toplumdaki din anlayışına bir başka örnek de ikizlerin cinayet 
sonrası kiliseye sığındıklarında gerçekleşen diyalogda görülebilir. Bu konuşmada ikizlerden Pedro cinayeti bilinçli işlediklerini fakat masum olduklarını düşündüklerini Peder'e söyler. Peder de buna karşılık olarak Tanrı katında öyle olabileceklerine ihtimal verdiğini belirtir. Buna karşılık Pablo' nun verdiği cevap oldukça çarpıcıdır, " Tanrı katında da, insanların gözünde de... Bu bir namus sorunuydu" (Marquez, 2014: 48).

Benzer şekilde piskopos üzerinden de eleştirel bir bakış açısı sunulmaya devam edilmiştir. Piskoposun aslında gemiden inmeyeceği, "Her zamanki gibi görev gereği hayır dua" edeceği ve "geldiği gibi dönüp" gideceği çünkü kasabadan nefret ettiği ifade edilir. Bu konuda haklıdır Placida Linero (Santiago'nun annesi) zira tüm roman boyunca olumsuz imgelerle anlatılan piskopos kasaba halkının arasına fiziki varlığı ile bizzat katılmamış ve bir anlamda inancının ruhani etkisini halka ulaştıramamış gözükmektedir. Öte yandan Doktor Dionisio'nun temsil ettiği ve toplumun aydın tabakasının dinle çatışmasını çağrıştıracak an okurun karşısına bir otopsi sahnesiyle çıkacaktır. Peder öldürülen Santiago'nun otopsi raporundaki sarılık hastalığı belirtisi nedeniyle doktoru suçlar, "'Yani' dedi bana 'zaten ancak birkaç yıllık ömrü kalmıştı" (Marquez, 2014: 70). Bu suçlama üzerine Doktor, "Bu kadar ahmak olmak için ancak papaz olmak gerekir, bizler gibi tropikal bölgede yaşayanların karaciğerlerinin İspanyollarınkinden daha büyük olduğunu adamın kafasına sokmak bir türlü mümkün olmadı" (Marquez, 2014: 70) diyerek eleştirir. Kısaca denilebilir ki kasaba halkının dini anlayışı olan Katolik inancı insanların dışı itibariyle saygı duyar gözüktüğü ama günlük yaşantılarına uzak bir pratiği ifade etmektedir. Herkes dini kendine göre yorumlamakta, yanlış eylemlerine bir kılıf olarak kullanmakta ve gerçek manada din adamlarına ve onlar da halka saygı duymamaktadırlar.

Marquez romanda Bayardo San Roman ve Santiago Nasar karakterleri üzerinden sosyal statü ve bunun getirdiği hukuki ve sosyal ayrıcalıkları vurgulamaktadır. Her iki karakter de varlıklı ve nüfuzludur. Bu yönleriyle toplum tarafından imrenilmektedirler. Ne ilginçtir ki para birçok konuda sosyal üstünlük ve ayrıcalık sağlarken namus konusu bu kapsamın dışında tutulmuştur. San- 
tiago Nasar zenginliğine rağmen Angela'nın namusunu lekeleyen kişi olarak toplumca suçlu kabul edilmiştir, "Tıpkı babası gibi tek başına dolaşır, o dağlarda önüne çıkan ne kadar başıboş kız varsa hepsinin tadına bakardı" (Marquez, 2014: 81). Bu yanlışı ile ölümü hak eder olarak görülmüş ve cezayı verecek olan ikiz kardeşlere de karışılmamıştır. Bununla birlikte zenginlik söz konusu olunca nüfuzun üstünlüğünün sağlayabileceği ayrıcalıklara vurgu yapılır. Bu durum bir kasabalının cinayete ihtimal vermeyen ifadesinde kendini gösterir, "Saçmalama... O ikisi kimseyi öldüremez, hele zengin birini hiç" (Marquez, 2014: 53). Varlıklı olmanın getireceği dokunulmazlık bir ayrıcalık olarak kişilerin algılarında sağlam yer etmiştir.

Diğer taraftan Bayardo San Roman, namus konusu ortaya çımadan önce Angela'yı evliliğe ikna etmek için kur yapmaktadır fakat sonuç alamayınca ilgisini kızın maddi anlamda dar olanaklara sahip ailesine çevirir. Angela'nın ailesi başlarına konan "talih kuşunu” (Marquez, 2014: 36) göz ardı etmezler. Bayardo'nun dügün için yaptığı büyük masraf bir statü göstergesidir ve kasabanın diğer zengini Santiago için aşılması gereken bir hedef olarak görülmektedir. Kendisi de benzer bir düğün arzuladığını ifade ederken (Marquez, 2014: 23) aslında Bayardo'yu kendine rakip olarak gördüğünü açıktan açığa hissettirir. Düğün masrafının Santiago tarafından ciddiyetle takip edilmesi Bayardo'nun da hoşuna gitmekte ve kasabadaki konumunu sağlamlaştırmaktadır. Sınıf üstünlüğü birçok kapıyı açar görünmektedir ve düğün mekânı olarak seçilen yer de buna bir göndermedir. Kişisel anılarına derinden bağlı Dul Xius'un evi büyük bir meblağ karşılığında düğün evi olsun diye satın alınmış ve toplumda ön plana çıkılmak istenmiştir çünkü bu ev kasaba halkı için bir statü sembolü konumundadır.

Toplumun suça bakış açısı da üstünde durulması gereken bir başka unsurdur. Arzu Yıldırım'a göre suç sosyolojik açıdan bir sosyal ortam olgusudur ve bunun getirisi olarak da asıl toplumun hasta olduğu sonucuna varılabilir. Bu bağlamda toplumdan topluma suç algısının değiş̧ebileceği de göz ardı edilmemelidir (2014: 4-5). Buna karşın kadının namusu meselesi birçok toplumca üzerinde uzlaşılan geçerli bir suç nedeni olarak görülmektedir. Toplumsal 
cinsiyet temelli sosyalleşme kadına yönelik şiddetin en baş sebepler arasında gelmekteyken (Yüksel vd. , 2017: 202) Kolombiya toplumunda da töreler namus nedeniyle öldürmeyi haklı kılmaktadır (Üretmen, 2016). Bu haklılığı ispat adına da çok fazla delil gerekmemektedir. Kırmızı Pazartesi' de Angela'nın bu tarz bir suçu ismen isnat etmiş olması yeterli görülmüş ve kendisinin beyanına itibar edilmiştir.

Cinayetin işlenmesi kadar işlenme şeklindeki vahşet de göz ardı edilmemelidir. İlkel yapım domuz kesme bıçaklarının (namus suçu işleyene olan bakışın bir sembolü olarak da anlaşılabilir) kullanılarak yedi ölümcül darbe (akla Hıristiyanlıktaki yedi ölümcül günah anlayışını çağrıştırmaktadır) ile hunharca delik deşik edilen Santiago bir süre bağırsakları elinde dolaşmıştır. Bu anlatım Marquez'in içinde yaşadığı Kolombiya halkının suç kültürüne olan yakınlığını düşündürtmektedir. Marquez'in yirmili yaşlarda olduğu ve gazetecilik yaptığı dönemde (1940-50) ülkede la Violencia dönemi (1948-1958) yaşanmış ve çokça insan iç savaşa kurban gitmiştir. Hatta bu dönem ile ilgili en büyük korku çağrışımının öldürülmek ya da yaralanmak değil paramparça edilmek olduğu belirtilmektedir (Hoyos, 2006: 8). Bu anlamda Santiago Nasar da namus uğruna verilen bir kurban olarak bu korkudan nasibini almiş gözükmektedir.

Ed Vulliamy, Marquez'in Kolombiya'nın yaşadı̆̆ı bu kanlı yılların gölgesini kendi yazınının çoğunda barındırdığından bahsetmektedir (2014). Zaten Héctor Hoyos da la Violencia döneminin Kolombiya edebiyatı üzerinde bir tür tutulma etkisi gösterdiğini ve yazınsal olarak milli ve küresel manada bu dönemin etkilerinin olumsuz bir seyri olduğundan bahsetmektedir. Dönemin siyasi çatışmalarının derinden sarstığ bu toplumda, 200.000 kişinin ölüp 2 milyon kişinin de yerinden yurdundan edilmesi ve şiddetin kendisinin la Violencia (şiddet) olarak adlandırılmasının aslında şiddeti besleyenlerin kimliğinden çok eylemin kendisine odaklanma amacı taşıdığının belirtilmesi bu döneme dair önemli ayrıntılardır. Bu dönemi yansıtan romanların ortak özelliğinin şiddetin kan dondurucu ayrıntılarının duyguları felç eden bir anlatım içermesidir. Bu durum G.G. Marquez'in benimsemediği bir yaklaşım ol- 
duğundan kendi yazınında bu boyutuyla yer almamıştır. Bunun yerine bir yandan dünya edebiyatı sınırları içerisinde kalıp diğer yandan da Kolombiya'nın kendi siyasi çıkmazlarını içeren orantılı bir şiddet anlatımını insana dair diğer izlekler ile harmanlayarak yazınında buluşturmuştur. Marquez şiddetin mağduru ölülerden çok yaşayanlara odaklanarak onların duygularını ve bakış açılarını yansıtmanın gerekli olduğundan bahsetmiştir (Hoyos, 2006: 3-14). Kırmızı Pazartesi kan donduran bir cinayetin anlatısı olarak bizzat G.G.Marquez tarafından biz okurlara cinayeti işleyen kardeşlerin toplumsal konumları ve bireysel yaklaşımları üzerinden kanlı eylemin perde arkasını görme imkanı tanımaktadır. Aynı zamanda cinayetin kültürel nedenlerine dair kavramsal bir zemin etüdünde bulunma imkânını vermekte ve şiddetin gücünü toplumsal olandan aldığını hissettirmektedir.

Kolombiya toplumun suça meyilli olduğunu iddia eden Waldmann'a göre bunu kantlayan sebeplerden biri de yasaklaylcı kuralların olmayışıdır (2007: 65). Waldmann buna örnek olarak "sicarios"u (adam öldüren) verir. Bu kişiler 15-25 yaş aralığında olup para karşılığında bu işi yapmaktadırlar. Aynı zamanda bu kişiler Bakire Meryem'i yüceltmekte ve kendi annelerini kutsallaştırmaktadırlar (Kasaba halkının bekâreti kutsal görmesi ve Bayardo'nun Angela'yı eve geri getirdiğinde kızın annesine hitaben, "Her şey için teşekkürler, anne. Siz bir azizesiniz" (Marquez, 2014: 47) demesi bu sicarioların tarzını anımsatmaktadır). Yine sicario'lar yöntemleri itibariyle acımasız, soğukkanlı ve duygusuz olarak tanımlanmakta, öldürecekleri kişiye hazırlık zaman tanımamakta ve bu eylemlerini kutsal sebeplere bağlamaktadırlar (Waldmann, 2007: 69-71). Yasaklayıcı kuralların eksikliği, Kolombiya toplumunun yetersiz dayanışma ve güven ruhuna sahip olması ve devletin güçlünün idaresindeki bir sistem olarak algılanması insanların daha küçük topluluklar halinde veya kendi çekirdek aileleriyle güçlü bağlar kurarak yaşamalarını beraberinde getirmiştir. Örf ve adetlerin hem samimi hem de katı olabildiği böylesi bir sosyal ortamı Marquez oldukça etkileyici bir anlatım ile yazıya geçirerek Katolik Hristiyanlığın hâkim olduğu bu topraklarda dini değerlere saygı ile şiddetin yaygınlığının karmaşık ilişkisini başarılı bir şekilde resmetmiştir. 


\section{Kuyucaklı Yusuf'ta Namus, Sosyal Statü-Değer ve Din Olgusu}

Benzer alt başlıklarla incelenecek diğer eser de Kuyucaklı Yusuf tur. Türk edebiyatı içerisinde müstesna bir yeri olan bu eser,

Rousseau'nun isyan ve doğaya dönüş felsefesinden kaynaklanan başkaldırı temasını işleyen ilk romandır. Aynı zamanda Anadolu'daki toplumsal düzene yönelik getirdiği eleştirel bakış açısıyla Türk romanının o döneme değin ana sorunsalı olan batılılaşmama dişına çıkmış ve 1950'lerde yaygınlaşmaya başlayan köy edebiyatına yönelişte de önemli rol oynamıştır. (Karaca, 2007: 119)

Eserin yazarı Sabahattin Ali'nin Türk edebiyatı içerisindeki müstesna konumu hakkında bilgi veren bir başkası da Aziz Şeker'dir. Kendisi benzer bir vurgu yaparak Tanzimat döneminden 1950'lere kadar gelen Türk romanının temel sorunsalını Batılılaşma hareketi olarak çerçevelendirmektedir. Bu anlamda Sabahattin Ali'nin fark $\imath$ döneminin aydınlarından ayrı olarak toplumsal meselelere olan hassasiyetini Batılılaşma hareketlerinden çok daha önce yazınına dâhil ederek "yarı-feodal bir toplumsal yapıdan kaynaklı çatışmaları işlemiş" olmasıdır (2019: 878-879). Ali bunu yaparken bir taraftan da kendi yaşamı içinden kimi ayrıntıları eserlerindeki kurguya yedirmiştir (Çalışkan, 2018: 426). Bu özelliğinden dolayı da Toplumcu Gerçekçi olduğu kadar 'gözlemci gerçekçi' özelliğini ortaya koymuş ve bu türde eser veren birçok başka yazarın düştüğü tuzağa düşmekten de kurtulmuştur. Onun kahramanları sadece Sabahattin Ali'nin ideolojilerini yansıtma misyonunu yüklenmiş değillerdir, aynı zamanda "canlı, duygu yüklü ve ...kalıcı" tipler olarak zihin dünyamıza konuk olmaktadırlar (Hasdedeoğlu, 2008: 159).

Mehmet Karakaş bir iktidar ilişkisini tanımlarken onun "başkalarının eylemleri üzerinde eyleyen bir eylem" olarak ifade etmektedir (2002: 157). Böylesi eylemlere maruz kalmış kahramanımız Yusuf da anne babasının eşkıyalar tarafından öldürülüşüne şahit olmuş bir oğlan çocuğudur. Yusuf, Salahattin Bey tarafından evlatlık alınarak sahip çıkılır. Yeni ailesi ile birlikte yaşayacağı Edremit kasabasındaki hayatı o dönemin toplumsal yapısı üzerinden çarpıcı ayrintılar ile sunulmaktadır. Yusuf etrafına yabancılık duyan bir 
çocuk ve gençtir. Bu "garip tabiatlı çocuk" (Ali, 2007: 18) kasabalıların oluşturduğu düzene yabancıdır ve "yerini bulamamanın azabını bütün teferruatıyla duymakta"dır (Ali, 2007: 147). Hatta Yusuf toplumdaki yapay ilişkilerden bunaldıkça kendini doğaya atmaktadır. Zaman içerisinde toplumsal kurumlardan (okul sıkıcıdır ona göre ve gereksiz bilgiler öğretmektedir) da sıkıldığı görülen Yusuf bir anda kasabadaki güç ve iktidar ilişkileri içerisinde bulur kendini. Üvey kız kardeşi Muazzez etrafında gelişen erkek egemen mücadele nedeniyle kasabanın sözü geçen ve zengin eşrafının düşmanlığını kazanır. Şakir ve babası Hilmi Bey ahlak yoksunu ve yozlaşmış kasaba eşrafının prototipleridir adeta. Rüşvet, tecavüz, adam kayırma ve cinayet gibi kötü fiilleri gayet rahat işlemektedirler zira "...başka türlü olmasına imkân yoktu(r). Bu böyle gelmiş, böyle gidiyor(du)" (Ali, 2007: 96). Aynı eşraf kasaba halkı üzerinde baskı kurar, kasabanın ileri gelen idarecileriyle çeşitli çıkar ilişkileri geliştirirler ve ne jandarma ne de hükümet onlara karışır "çünkü onlar parayı bolca oynatırlar" (Ali, 2007: 33). Bu iktidar mücadelesi içerisinde Yusuf birkaç kez dönen bu çarka çomak sokmayı başarır (Muazzez'le evlenir, Selahattin Bey'in kumar borcunu öder ve tecavüz mağduru kıza sahip çıkar) ama yine de romanın sonunda bu çarkın dişleri arasında ezilir (karısını kaybeder ve kasabanın ileri gelenlerini öldürerek "atını ileriye, dağlara doğru" yani belirsiz bir geleceğe sürer (Ali, 2007: 215). Toplum düzenine başkaldırının öncü örneklerinden biri olan bu roman okuyucuya bedeli ödenerek de olsa bunun gerçekleştirilebileceğini anlatmaya çalışır.

Bir başka toplumsal olgu da dindir ve Kuyucaklı Yusuf ta bireysel ve toplumsal boyutta ele alınmıştır. Bireysel olarak Yusuf'un Selahattin Bey'in ölümü üzerine kendi dini yaklaşımını betimlediği şu ifadeler göze çarpmaktadır;

Yusuf' un camiyle, namazla, din ve imanla pek alışverişi yoktu. Hele babası, Şahinde`nin tabiriyle "kızıl gâvur"du. Fakat minareden kopup... takılan bu feryat onu kendinden geçirdi. ...Bir müddet sonra etrafındakilerin yerlerinden kalktıklarını, camiye doğru yürüdüklerini gören Yusuf doğruldu. Cenaze namazına iştirak etti. Sessiz bir kafilenin içinde ve başı önünde mezarlığa kadar gitti. (Ali, 2007: 161-162) 
Günlük hayatında dine ait gereklilikleri pek dert edinmeyen Yusuf'un ölüm karşısında sorguladığı insanın varlığı ve değerli hatırası dine anlık bir yakınlaşma hissetmesine sebep olur. Bu anlamda Ali, Yusuf üzerinden ortalama bir kişinin sergileyeceği dini anlayış tavrını aktarmıştır. Toplumsal yönüyle de din Ramazan ayı üzerinden ele alınmıştır;

... yeknesaklığını değiştiren... bayramlardı. Hele ramazan bayramı, bir aylık bir bekleyiş ve hazırlıktan sonra geldiği için, o nispette coşkun olurdu. Çocukların çoğu ramazanda oruç tutar, namaz kılarlardı. Sahura kalkmak ayrı bir zevk, ... mahmurlukla, dolaşmak ayrı bir zevkti. ... Hoca'nın vaazları dinlenir, ikindi mukabeleleri kaçırılmaz ... ...Top patlar patlamaz, ... evlerine koşuştururlard1. ... teraviye giderler... büyüklerin yokluğundan istifade ... oynarlardı. ... perşembe akşamlarını sabırsızlıkla beklerlerdi. ... Kadiri tekkesinde zikir olduğu için, çocuklar tekkenin etrafında dizilirler... kadınları seyrederler, ... "hünküren" dervişlere bakarlardı. ... ...bayram, sahiden bir coşkunluk ve neşe devri olurdu.(Ali, 2007: 28-29)

Toplumsal boyutuyla anlatımda dikkat çeken unsur dine ait olumlu anlatımın daha çok çocuklar üzerinden yapılmış olmasıdır. Din olgusunun yetişkinlerin dünyasını şekillendiren bir boyutundan pek olumlu bahsedilmemekte aksine "hızlı hızlı namaz kıldıran" bir imam ve "secdeye varanların patırtısı " (Ali, 2007: 72) ile "kirli bir seccadenin üstünde yatıp kalk(an)" kişilere bakarak "kendi için de böyle bir hayat tasavvur etmek" istememesi anlatılmaktadır (Ali, 2007: 152). Yine benzer bir örnek de, "Bu alevi köylerinin daha geniş mezhepli, daha temiz ve daha samimi olduğunu ona uzun memuriyet seneleri öğretmişti(r)" (Ali, 2007: 139). Bu anlamda Sabahattin Ali'nin, bireylerin veya toplumun üzerindeki din tesirini anlatırken kullandığı anlatım tekniği ile hikâyenin satır aralarına girerek okura kendi fikirlerini açıklıyor görünmektedir. Ayrıca dini motiflerden ziyade namus anlayışının romanın sonunu belirler gözükmesi de din olgusunun daha ikincil etkisine işaret etmektedir. 
Kuyucaklı Yusufta kadın ve namus meselesine olan yaklaşım Kırmızı Pazartesi'ndekine benzer özelliktedir. Edremit kasaba halkı içinde kadınlar genelde edilgen olarak yansıtılmışlardır. Hikâyenin baş kadın karakteri olan Muazzez roman boyunca edilgen yapıdadır ve çeşitli arzu üçgenleri (Özer, 2013) içerisinde hep başkalarının onu yönlendirmesine göre şekil alır. Kendini istemediği durumlardan kurtarmak adına yaptığı bir eylem yoktur. Bu toplum içerisinde de kadınlar "bazı iyi kalpli ve alakalı komşuların sayesinde nakış, gergef ve biraz da dikiş öğreniyor" ve hatta kaymakam kızı olarak da "kendisiyle akran olan kızlarla beraber terzi Mürüvvet Hanım'dan ut dersi alıyordu"r (Ali, 2007: 27). Kadınlar kendilerine çizilmiş sınırlar içerisinde varlık sürdürürken namusları da erkeklerden sorulur görünmektedir. Örneğin, Yusuf Muazzez'in Terzi Mürüvvet Hanım'dan ders almasını yasaklar çünkü etraftan "münasebetsiz rivayet(ler)" duymuştur (Ali, 2007: 28). Yine Muazzez ile alakalı olarak kasabanın zengin ve ahlak yoksunu delikanlısı Şakir'in art niyetli emelleri sonucu tecavüz mağduru Kübra'yı evine alarak koruması Yusuf'un namus konusundaki himayeciliği hakkında okura bir fikir vermektedir. Hatta romanın sonunda evlendiği karısı Muazzez'in kendisinin yokluğunda maddi imkânsızlıkların pençesindeyken annesi Şahinde Hanım'ın da tesiriyle kasaba eşrafının içki masalarına misafir edilişini öğrendiğinde evindeki eğlenceyi basması ve bu ahlaksızlığın önde gelenlerini öldürürken yanlışlıkla karısını da yaralaması bu duruma verilebilecek örnekler arasında sayılabilir. Zira "Bu evin namusu benden sorulur" (Ali, 2007: 194) fikrine sahip olan Yusuf için artık ok yaydan çıkmıştır;

Uzun senelerden beri nefsine karşı yaptığı tahakkümlerin acısı çıkıyor, içinde boşandığını hissettiği bir çarkı artık durduramayacağını anlıyordu. Bu anda bütün hayatıyla, bütün muhitiyle, bütün dünya ile hesap kesiyor ve bu hesaplaşma, şimdiye kadar her şeye baş eğdiği nispette korkunç oluyordu. (Ali, 2007: 209)

$\mathrm{Bu}$ alıntıda kasabadaki toplumun yozlaşmış ileri gelenlerinden olup da namusunu kirletenlere çoktandır yapılması gerekeni yapacağı görülmektedir. Romanda namus kavramı başka yerlerde de geçer. Örneğin, kasabanın kabadayıları namusludur (20), 
Kübra'nın annesi (42) ve Selahattin Bey (110) namuslu damat adayı arayışındadırlar, Salahattin Bey eşrafın kirli işlerine bulaşmadan namuslu kalmaya çabalar (44) ve namuslu komşular (190) Yusuf'un yokluğunda evinde dönen dolaplardan haberdardırlar ama meseleyi düzeltip müdahil olacak yetişkin yoktur. Gençler askerdedir ve geriye de sadece ihtiyarlar ve sakatlar kalmıştır ki onlar da geçim derdi ile boğuşmaktadırlar. Namus konusunun çetrefilli olmasının önemli bir başka sebebi de "parası olanın 1rzı da tamam, namusu da!" (118) anlayışıdır. Parasal gücü olanların eylediklerini düzeltmek için toplum tarafından ortaya konabilecek bir refleks gelişmemiştir. Bu irade zafiyeti Şakir ve babası Hilmi Bey'in tecavüzüne uğrayan Kübra meselesinde de yaşanır. Ne Kübra ne de annesinin hesap sormaya gücü yetmez. Hatta kadın Salahattin Bey'e söylediğinde kaymakam laf olsun diye bile hesap soracağını belirten söz söyleyemez zira kurulu toplumsal düzeni sorgulamak oldukça zordur.

Bir başka ilginç durum da Kübra'nın yaşadıklarını utancı nedeniyle kimseye anlatamamış olmasıdır. Ferda Zambak'a göre romanda kadın karakterlerin mağduriyetleri, toplumun cinsiyetçi algılar üzerinden ürettiği normlarla yakından ilişkilidir. Buna göre erkek, kontrol hiyerarşisinde rol alır. Eşitsizliğin oluşturduğu hiyerarşide, kadın her bakımdan erkeğe bağlı bir algı içerisinde değerlendirilir. Kadın bedeni üzerinden tanımlanan namus kavramı da bu anlayıştan payını alan bir yapıdadır. "Ataerkil toplum düzeninde eril bir nitelik olarak kabul gören namusun kadın benliğinde yer buluşu 'utanç' yoluyla olmaktadır. Bu yüzden Kübra'nın, uğrayacağı felaketin ilk işaretlerini fark etmesine rağmen, bunu bir utanç olarak algılayarak susmayı tercih etmesi, toplumsal cinsiyetin kadın ve bedeni üzerinden oluşturduğu denetleyici, hegemonyacı algıyla yakından ilişkilidir (2017: 368).

\section{Sonuç Gözlemleri}

Sonuç olarak denilebilir ki hem Kırmızı Pazartesi hem Kuyucakı Yusuf içinden çıktıkları toplumsal gerçekliği başarılı bir şekilde yansıtan yazınsal anlatılardır. Bu bağlamda toplumcu gerçekçi yaklaşım üzerinden bu iki eser ayrıntılı olarak tahlil edilebilir. Her iki toplumda maddi gücün sağladığı bir toplumsal dokunulmaz- 
lık vardır ve toplumun tüm bireyleri tarafından içselleştirilmiştir. Her iki romandaki başkahramanlar toplumsal beklentiye karşı mücadele etmeye çabalarlar fakat yine de toplumun sınırlarını belirlediği alan içerisinde kalır tüm mücadele. Pablo ve Pedro Vicario kardeşler kendilerinden bekleneni yaparak namus lekesini temizlerler (isabet edip etmedikleri ise sorgulanmaz). Yusuf da her ne kadar toplum düzenine uzak kalmaya çalışmış olsa da yine de kısmi bir başkaldırı ile birlikte tüm hayatını ve eşini bu uğurda feda etmek zorunda kalmıştır. Bu bağlamda Santiago her toplumda ortaya çıkabilecek bir tipik karakterdir. Namus suçu işlediğine hükmedildiğinden sosyal statüsü onu kurtarmaz ve toplumsal linç kültürü tarafından kurban verilir. Yusuf da olumlu karakter tiplemesine uygun görünmektedir, duyarlı, karamsar, fedakâr ve eylemi erteleyen ya da hiç eyleme geçemeyen bir bireyi temsil eder olarak betimlenmiştir.

Sosyolojik eleştiri bağlamında her iki romanda din, sosyal statü, namus ve değerler sistemi örnekler üzerinden incelenmiştir. Din olgusu Kırmızı Pazartesi'deki olay örgüsünde daha yoğun yer almıştır. Katolik inancının halk nezdinde değerli ve muteber oluşu her ne kadar ironik ve alaycı betimlemelerle aktarılsa da kahramanların davranışlarına olan tesiri göz ardı edilemez. Diğer yandan $\mathrm{Ku}$ yucaklı Yusuf ta din olgusu daha kişisel bir bakış üzerinden aktarılmıştır. Çocukların dünyasına dair ve onların gözünden din olgusu daha olumlu günlük tesirler üzerinden tasvir edilmiştir. Yetişkinlerin bakış açısı da daha ziyade Yusuf'un üzerinden sunulmuş ve bunun da çok bağlayıcı bir etkisinin olmadığı gözlemlenmiştir. İki kitap arasındaki bu farklılıkta romanlarda kullanılan anlatım tekniğinin bu sonucu doğurmuş olabileceği düşünülebilir zira Kırmızı Pazartesi'nde sayıca çok anlatıcı varken Kuyucaklı Yusuf ta olaylar daha çok üçüncü tekil şahıs üzerinden aktarılmıştır. Bu durum da bizlere din olgusunun toplumsal görünürlük ve etkisinin sınırlandırılmış olarak algılanıp aktarıldığını düşündürtmektedir.

Namus anlayışı ve bununla bağlantılı değerler açısından her iki romanda kadına olan bakış açısı benzerdir. Hem Angela Vicario hem de Muazzez (ki her iki isim de aziz tutulan, yüceltilen kişi veya kişilik manasındadır) toplumun öngördüğü bir cinsiyet tanımına göre yaşayarak kaderleri konusunda edilgen konumda 
bulundurulurlar. Yine her ikisi çifte standartlı namus anlayışı yüzünden zarar görmüşlerdir. Angela namusuna sürülen leke nedeniyle kocası tarafından terk edilip uzun yıllar boyunca toplumdan tecrit edilirken Muazzez de bunun bedelini kocasının eliyle gelen şiddet yüzünden canıyla ödemiştir. Toplumun namus söz konusu olunca hata örtücü olmak yerine dedikodularla olayı manipüle ettiği, gerçek failleri cezalandırmak veya erkeğe de aynı namus standartlarını koymak yerine adeta belli kişileri kurban seçtiği, hem zamanında müdahil olmayarak sorumluluktan kaçındığ hem de buna rağmen toplumsal değer sistemini doğrudan yana şekillendirmediği gözlemlenmiştir.

Bu çalışmanın bir diğer bulgusu da Santiago Nasar ve Yusuf'un kendi toplumları içerisinde adeta bir tür günah keçisi gibi görüldükleridir. Nasar gerçekten suçlu mudur bu tam olarak kestirilemez ama onun öldürülüşü namus meselesini çözmüş görünmektedir. Yusuf da kasabadaki statü dengelerini bozarak özellikle Şakir ve Hilmi Bey gibi önde gelenlerin gücünü sorgulamış ve sonunda da ölümlerine sebep olmuştur. Jeramy Townsley'e göre bir toplumda günah keçisi seçmenin birkaç sebebi vardır (2003). Öncelikle bu kişi tam olarak kendi toplumundaki problemlerin asıl nedeni değildir (Santiago belki de bu suçu işlememiştir ve Yusuf kendisini uzak tutmak istediği halde belli kişiler onu veya ailesini hedef almıştır). Yine bu kişiler dışlanmış ve dışarıdan olmakla birlikte (Santiago Arap kökenlidir, Yusuf ise kasabaya evlatlık gelmiştir) yine de o topluma kısmen yakındırlar (Santiago kasabaya yerleşmiş babasının ismini sürdürmekte, Yusuf da kaymakamın evlatlığı olarak ezilmiş halkın yanında yer almaktadır). Bu kişilerin diğerlerinden farklı bir yanının olması da günah keçisi olmaları adına belirleyici bir faktördür. Toplumun genelinden farklı olarak Santiago oldukça varlıklı ve etnik bakımdan yabancıdır, Yusuf da tuhaf kişilikli ve topluma mesafelidir. Bahsedilen bu özelliklerinden dolayı Santiago ve Yusuf kendi toplumlarının süregelen sorunlarının çözümü adına günah keçisi olarak öne sürülmüş ve hayatları karartılmış kişilerdir. Bireyin karartılan hayatından gelen bu devinim üzerinden de toplum kendini tekrardan üretmiş olmaktadır. 


\section{Kaynakça}

Ali, S. (2019). Kuyucaklı Yusuf, 87.bs, İstanbul: Yapı Kredi Yayınları.

Bektaş, N. (2009). Toplumcu Gerçekçilik Bağlamında Nazım Hikmet'in 'Ferhad ile Şirin' Oyununa Metinlerarası bir Bakış, An Intertextual Approach to Nazım Hikmet's Play 'Ferhad and Şirin' in the Context of the Socialist Realism, Milli Folklor, 21(83), 41-47, Erişim Adresi: http: / / www.millifolklor.com/ PdfViewer.aspx?Sayi $=83 \&$ Sayfa $=38$

Çalışkan, A. (2018). Ana Çizgileriyle Cumhuriyet Devri Türk Hikâye Ve Romanına Teorik Bir Yaklaşım (1923-1939), Turkish Studies Social Sciences, 13(18), 365-485, DOI Number: http: / / dx.doi.org/10.7827/TurkishStudies.13975

Darıcı, İ. (2017). Kırmızı Pazartesi - Gabriel García Márquez, Insanokur, Erişim Adresi: http://www.insanokur.org/ kirmizi-pazartesi-gabriel-garcia-marquez /

Hasdedeoğlu, M.O. (2008). Toplumcu Gerçekçilik Ve Sabahattin Ali'nin Hikâye Kişileri, (Yayınlanmamış Yüksek Lisans Tezi). İstanbul Kültür Üniversitesi Sosyal Bilimler Enstitüsü.

Hoyos, H. (2006). García Márquez's Sublime Violence and the Eclipse of Colombian Literature, Chasqui, 35 (2), 3-20.

Hudson, R.A. (2010). Colombia a Country Study, 5. bs. , Federal Research Division Library of Congress.

Karaca, A. (2007). Kuyucaklı Yusuf Roman Özeti - Sabahattin Ali, Anasayfa, Erişim Adresi: http://www.turkedebiyati.org/ kitap_ozetleri/kuyucakli-yusuf.html

Karakaş, M. (2002). İktidar İlişkileri Açısından Bilim ve Sosyoloji, Sosyal Bilimler Dergisi, Cilt 4, Sayı 1, 154-169.

Marquez, G. G. (2014). Kırmızı Pazartesi (İnci Kut, Çev.), İstanbul: Can Yayınları.

Moran, B. (1999). Edebiyat Kuramları ve Eleştiri, (23.bs), İstanbul: İletişim Yayınları.

Özer, H. (2013). Kuyucaklı Yusuf'ta Arzu Üçgenleri, Türk Dil, Edebiyat Ve Halkbilimi Araştırmaları Dergisi, 399-408.

Porter, T. (2018). The Secret Story of a Terrible Love: A Love Story Masquerading as a Crime Novel. Erişim Adresi: http: / / www. bowdoin.edu/news / 2018 / 02 / the-secret-story-of-a-terriblelove-a-love-story-masquerading-as-a-crime-novel.html 
Şeker, A. (2019). Kuyucaklı Yusuf RomanınınKadınKahramanlarını Toplumsal Cinsiyet Bağlamında Psikososyal Yönleriyle Ele Almak, İnsan $\mathcal{E}$ İnsan, 6(22), 865-881. Erişim Adresi: DOI: https: / / doi.org/10.29224/insanveinsan.521714

Tepeler, S. (2013). Kırmızı Pazartesi Toplumunun Sosyo-Kültürel Açıdan İncelenmesi, ST Akademik Paylaşımlar. Erişim Adresi: http: / / www.selimtepeler.wordpress.com / 2013/11/24 / kirmizi-pazartesi-toplumunun-sosyo-kulturel-acidanincelenmesi/

Townsley, J. (2003). Rene Girard's Theory of Violence, Religion and The Scapegoat. Erişim Adresi: http: / / www.jeramyt.org/papers / girard.html.

Üretmen, P. K. (2016). Toplumun Karanlık Yüzü: Kırmızı Pazartesi, Kitap Eki. Erişim Adresi: http://www.kitapeki. com/toplumun-karanlik-yuzu-kirmizi-pazartesi/.

Vulliamy, Ed. (2014). Gabriel Garcia Marquez: 'The Greatest Columbian Who Ever Lived', The Guardian. Erişim Adresi: http: / / www.theguardian.com/books/2014/apr / 19 / gabrielgarciamarquez-colombia

Waldmann, P. (2007). Is There a Culture of Violence in Colombia? International Journal of Conflict and Violence. Erişim Adresi: http:/ / www.ijcv.org/index.php/ijcv/article/ viewFile/21/21

Yıldırım, A. (2014). Sosyo-Kültürel Yapı ve Suç Olgusu Arasındaki İlişki: Malatya İli Örneği, KMÜ Sosyal ve Ekonomik Araştırmalar Dergisi 16, Özel Sayı 1, 1-7.

Yüksel, M. , Güllüpınar, F. , Yazgan, Ç.Ü. , Paker, E. B. , Gökalp E. , Suveren, Y. , Yavuz, S. , Taştan, C. (2017), Suç Sosyolojisi, (F. Güllüpınar, Ed.) Eskişehir, Anadolu Üniversitesi Yayınları.

Zambak, F. (2017). Gecikmiş İradenin Gölgesindeki Hayatlar: Kuyucakl Yusuf'ta Mağlup Kadınlık ve Erkeklik. Erişim Adresi: http:// www.kesitakademi.com 